\title{
Anticonvulsant and sedative activities of aqueous leave extract of Leucas martinicensis (Jacq.) R. Br.
}

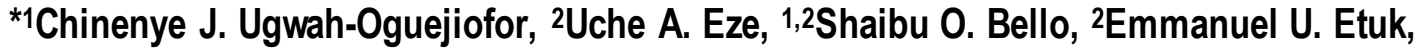 \\ ${ }^{3}$ George I. Ameh and 20 guejiofor M. Ugwah \\ 1Department of Pharmacology \& Toxicology, Faculty of Pharmaceutical Sciences, \\ Usmanu Danfodiyo University, Sokoto, Nigeria \\ 2Department of Pharmacology, College of health Sciences, Usmanu Danfodiyo University, Sokoto, Nigeria \\ 3Department of Microbiology, College of health Sciences, Usmanu Danfodiyo University, Sokoto, Nigeria \\ [“Corresponding Author E mail: nenye789@yahoo.com; : : +234 803609 8241]
}

ABSTRACT: Leucas martinicensis is a medicinal plant used in traditional medicine to treat convulsions and epilepsy. The presentstudy was to evaluate the anticonvulsant and sedative effects of the aqueous leave extract of $L$. martinicensis in Wistar rats. The anticonvulsant activities of $L$. martinicensis (50, 100,200 or $400 \mathrm{mg} / \mathrm{kg}$ i.p.) were evaluated using maximal electroshock seizure (MES) - and strychnine (STR) -induced seizure models while the sedative properties were evaluated using the diazepaminduced sleep model in Wistar rats. The $400 \mathrm{mg} / \mathrm{kg}$ of the extract protected rats (100\%) against seizures in both models while at $200 \mathrm{mg} / \mathrm{kg}$ seizure protection (100\%) was only in STR model. There was a significant $(p<0.05)$ delay in the onset and reduction in the duration of seizure in the two models in unprotected rats. L. martinicensis exerted sedative effect by significantly reducing the onset (sleep latency) and increasing the total duration of sleep induced by diazepam. These results suggest that aqueous extract of $L$. martinicensis may possess anticonvulsant and sedative properties that might show efficacy against primary generalised seizures and secondarily generalised tonic-clonic seizures in humans. It also lends pharmacological credence to the use of the plant in traditional medicine for the management of epilepsy and convulsions.

Keywords: Leucas martinicensis; Epilepsy; Traditional medicine; Anticonvulsant; sleep

\section{INTRODUCTION}

Epilepsy is one of the commonest chronic neurological disorders which are estimated to affect 60 million people or more worldwide (Alexopoulous, 2013). It is a heterogeneous syndrome often characterized by recurrent and spontaneous seizures (Sasa, 2006). Several attempts have been made to treat/manage this disorder using antiepileptic drugs (AED). The current therapeutic treatment of epilepsy with modern AED is associated with side effects, dose related toxicity, pharmacoresistance and teratogenic effects (Loscher and Schmidt, 2002; Scharfman, 2007). A lot of people who are in search of safer alternative result to the use of traditional or complementarylalternative medicine in the treatment of this disorder.

Medicinal plants have been utilized by $80 \%$ of the population of the third world countries to treat various ailments (WHO, 1996). Evidence based traditional medicine has shown that some of these herbs are potent in alleviating manyhealth conditions including epilepsy. Plants that have been proven to possess anticonvulsant activities include Carissa edulis (Ya'u et al., 2008), Cotyledon orbiculata (Amabeoku et al., 2007), Evolvulus alsinoides (Abubakar et al., 2013) and Ficus religiosa (Patil et al., 2011). Many others such as Leucas martinicensis have been used empirically to treat convulsions and epilepsy without scientific proof of efficacy.

The genus Leucas comprises about 80 species (Hedge, 1990). Leucas martinicensis (Jacq.) R. Br. (Lamiaceae) is a native plant to South America, West Indies and may be native or introduced in Africa (Muhammad et al., 2012). It is commonly known as Whitewort or mosquito plant and 'Bunsurun fadama' in the Northern part of Nigeria. L. martinicensis is an erectstrong aromatic annual herb growing up to $1.5 \mathrm{~m}$ high. It is widely distributed in the tropical parts of Africa, Arabia, Asia and America (Muhammad et al., 2012). The decoction of the leaves of this plant is used in traditional medicine to treat many ailments (kidney disorders, rheumatism inflammations, cough, diarrhoea, fevers, skin rashes, epilepsy and convulsions) (Minja, 1999; Agra et al., 2007).

Pharmacological studies revealed in Leucas species antimalaria (Valsaraj et al., 1997), anti-inflammatory (Reddy et al., 1986) and antidiabetic (Saha et al., 1998) activities. Phytochemical analysis of this plant showed the presence of alkaloids, saponins, 
flavonoids and glycosides (Ezeh et al., 2013). The present study was to evaluate the anticonvulsant and sedative properties of aqueous leave extract of $L$. martinicensis in Wistar rats.

\section{METHODOLOGY \\ Plant material}

Fresh leaves of $L$. martinicensis were collected in Kara local market of Sokoto in the Month of March. A voucher specimen (020) was authenticated and deposited in the Taxonomy unit of the Department of Botany, Usmanu Danfodiyo University, Sokoto. The leaves were washed, air dried to a constant weight and pulverized mechanicallyinto a dried powder. 380 $\mathrm{g}$ of the dry powder were macerated in $2.5 \mathrm{~L}$ of distilled water for $24 \mathrm{~h}$. The mixture was occasionally stirred throughout the period. Filtration was carried out initially with muslin cloth and finally with Whatman filter paper. The filtrate was evaporated in a hot air oven at $45^{\circ} \mathrm{C}$ with a percentage yield of $4.27 \% \mathrm{w} / \mathrm{w}$. The resultant dry powder was suspended in distilled water and subsequently administered to the rats according to their dose group.

\section{Drugs and Chemicals}

Strychnine was obtained from Sigma Chemical, USA while diazepam was supplied by Hoffmann-La Roche (Roche Pharmaceuticals, 340 Kingsland Street Nutley, New Jersey 07110).

\section{Experimental Animals}

Adult male Wistar rats of 10-12 weeks old (170-180 g) which was obtained from the animal facility centre of our university were used for the experiment. The animals were housed under controlled conditions at a temperature of $25 \pm 2 \circ \mathrm{C}$, with $12 \mathrm{~h}$ light/dark cycles. Food and water were provided ad libitum. The care and handling of the animals were in accordance with the Animal Research Regulation 1985-2010 and the Organisation for Economic Development (OECD) guidelines on good laboratory practice (Organisation for Economic Development, 2008).

\section{Anticonvulsant Studies Maximal Electroshock (MES) Model}

Rats were divided in six groups of 6 rats and received various treatments. Group I received distilled water. Groups II to V (test groups) were administered with 4 doses $(50,100,200,400 \mathrm{mg} / \mathrm{kg}$ i.p.) of the plants extract. Group VI (reference group) was treated with diazepam at a dose of $3 \mathrm{mg} / \mathrm{kg}$ i.p. After $30 \mathrm{mins}$ of the treatment, hind limb tonic extension (HLTE) of rats were induced by passing alternating electrical current $(60 \mathrm{~Hz}, 30 \mathrm{~mA}, 0.2 \mathrm{~s})$ through eye electrodes (Ngo Bum et al., 2009; Ngo Bum et al., 2001). The animals that did not show HLTE within 10 mins were considered protected. The number of rats protected was determined in each dose group. The latency and duration of seizures were also determined in the unprotected rats using a stop watch.

\section{Strychnine (STR) test}

Six groups of 6 rats were treated 30 mins before the administration of STR (3 mg/kg i.p.) as discussed previously. Theywere placed in individual cages and observed. Latency and duration of convulsion, percentage of animals protected and percentage of death within $24 \mathrm{~h}$ were noted (Yemitan and Adeyemi, 2005; Czuczwar and Frey, 1986). The animals that did not show clonic or tonic convulsion within 10 mins of strychnine administration were considered protected.

\section{Sedative Effect \\ Diazepam-induced sleep in rats}

Rats were divided in five groups of 6 rats each and treated with distilled water as the control group and plant extract comprising 4 groups $(50,100,200$ or $400 \mathrm{mg} / \mathrm{kg}$ i.p. group). Thirty minutes after, all the groups received diazepam (5 mg/kg i.p.). The time from the injection up to the loss of the righting reflex is recorded as sleeping latency and the time between the loss and voluntary recovery of the righting reflex is recorded as the duration of sleep using a stop watch (Wambebe, 1985).

\section{Statistical Analysis}

All results are presented as mean \pm standard error of mean (SEM). They were analysed using graph pad prism version 6 software. One-way analysis of variance (ANOVA) was used to compare all groups followed by Students t-test. Differences were considered significant at $p<0.05$.

\section{RESULTS}

The extract of $L$. martinicensis, like the diazepam, completely protected rats at the dose of $400 \mathrm{mg} / \mathrm{kg}$ against HLTE caused by MES induced seizures (Table 1). In the unprotected rats, the latency of seizure (sec) was significantly $(p<0.05)$ higher than the control at all dose levels. The duration of seizure (min) was significant only in the 200 and $400 \mathrm{mg} / \mathrm{kg}$ dose levels. There were no deaths recorded.

In the STR- induced seizure model (Table 2), complete protection of rats was observed with $L$. martinicensis at doses of 200 and $400 \mathrm{mg} / \mathrm{kg}$. A significant $(p<0.05)$ increase in latency and reduction in duration of seizure were observed in 50 and 100 $\mathrm{mg} / \mathrm{kg}$. In this model, all animals died within $24 \mathrm{~h}$. 
In the diazepam-induced sleep test, the extract of $L$. martinicensis in a dose related manner, significantly $(p<0.05)$ decreased the onset of sleep time (sleep latency) at all dose levels (Fig 1) and increased the duration of sleep (Fig 2).

Table 1: The effect of $L$. martinicensis on the convulsions induced in rats by MES

\begin{tabular}{lllll}
\hline $\begin{array}{l}\text { Group/Doses of } \\
\text { L. martinicensis }\end{array}$ & \% of Protection & $\begin{array}{l}\text { Latencyof } \\
\text { seizure(s) }\end{array}$ & $\begin{array}{l}\text { Duration of Seizure } \\
\text { (mins) }\end{array}$ & \% of Survival \\
\hline $50 \mathrm{mg} / \mathrm{kg}$ & 0 & $4.5 \pm 0.39^{\mathrm{a}}$ & $5.33 \pm 0.30$ & 100 \\
$100 \mathrm{mg} / \mathrm{kg}$ & 0 & $4.8 \pm 0.64^{\mathrm{a}}$ & $3.83 \pm 0.28^{\mathrm{a}}$ & 100 \\
$200 \mathrm{mg} / \mathrm{kg}$ & 0 & $5.0 \pm 0.66^{\mathrm{a}}$ & $2.5 \pm 0.39^{\mathrm{a}}$ & 100 \\
$400 \mathrm{mg} / \mathrm{kg}$ & $100^{\mathrm{a}}$ & - & - & 100 \\
Diazepam $(3 \mathrm{mg} / \mathrm{kg})$ & 100 & - & - & 100 \\
Distilled water & 0 & $1.8 \pm 0.37$ & $5.35 \pm 0.45$ & 100 \\
\hline
\end{tabular}

Data are mean \pm SEM, $n=6$ per dose, a $p<0.05$ vs control (Distilled water)

Table 2: The effect of $L$. martinicensis on the convulsions induced in rats by Strychnine

\begin{tabular}{lllll}
\hline $\begin{array}{l}\text { Group/Doses of } \\
\text { L. martinicensis }\end{array}$ & \% of Protection & $\begin{array}{l}\text { Latency of } \\
\text { seizure(s) }\end{array}$ & $\begin{array}{l}\text { Duration of Seizure } \\
\text { (mins) }\end{array}$ & $\begin{array}{l}\text { \% of Survival } \\
\text { within } 24 \mathrm{~h}\end{array}$ \\
\hline $50 \mathrm{mg} / \mathrm{kg}$ & 0 & $4.6 \pm 0.45^{\mathrm{b}}$ & $4.65 \pm 0.22^{\mathrm{b}}$ & 0 \\
$100 \mathrm{mg} / \mathrm{kg}$ & 0 & $6.0 \pm 0.33^{\mathrm{b}}$ & $3.12 \pm 0.14^{\mathrm{b}}$ & 0 \\
$200 \mathrm{mg} / \mathrm{kg}$ & $100^{\mathrm{b}}$ & - & - & 0 \\
$400 \mathrm{mg} / \mathrm{kg}$ & $100^{\mathrm{b}}$ & - & - & 0 \\
Diazepam $(3 \mathrm{mg} / \mathrm{kg})$ & 100 & - & - & 0 \\
Distilled water & 0 & $2.0 \pm 0.33$ & $7.17 \pm 0.37$ & 0 \\
\hline
\end{tabular}

Data are mean \pm SEM, $n=6$ per dose, ${ }^{b} p<0.05$ vs control (Distilled water)

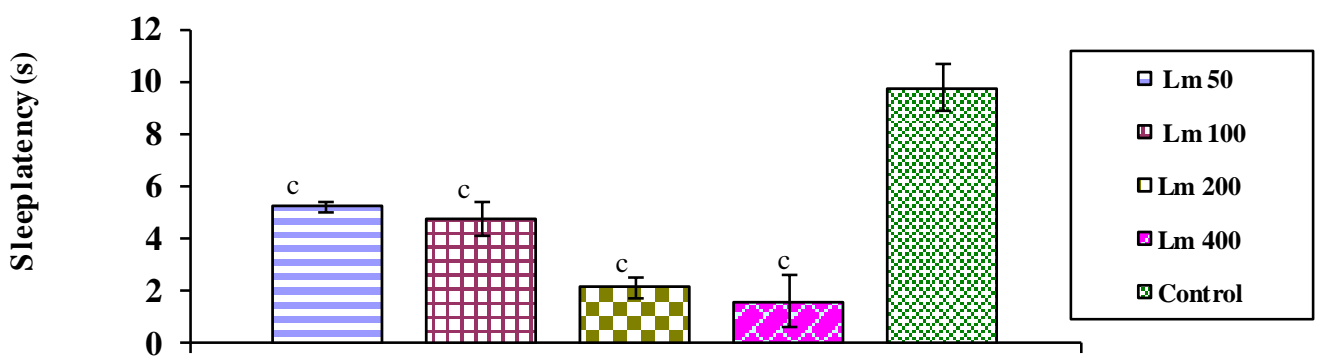

Treatment

Figure 1. Effect of $L$. martinicensis on sleep latency time induced by diazepam ( $5 \mathrm{mg} / \mathrm{kg})$.

The results are presented as mean \pm S.E.M. $n=6$ per dose, $c p<0.05$ as compared to control. $L m=L$. martinicensis $(\mathrm{mg} / \mathrm{kg})$.

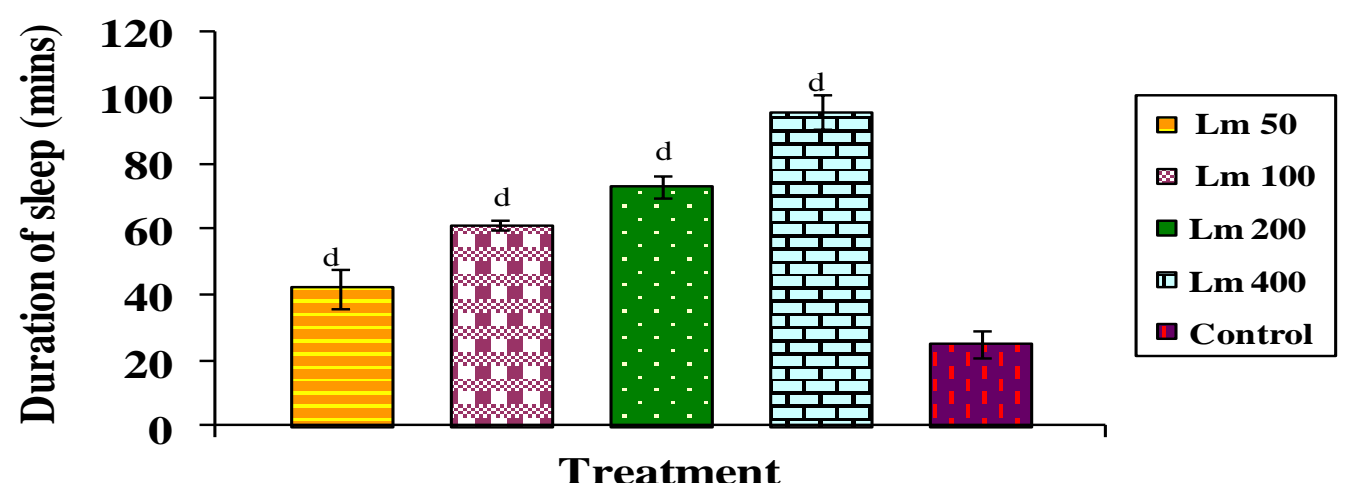

Figure 2. Effect of $L$. martinicensis on duration of sleep induced by diazepam $(5 \mathrm{mg} / \mathrm{kg})$.

The results are presented as mean S.E.M. $\mathrm{n}=6$ per dose, $\mathrm{d} p<0.05$ as compared to control. $\mathrm{Lm}=\mathrm{L}$. martinicensis $(\mathrm{mg} / \mathrm{kg})$. 


\section{DISCUSSION}

The present study demonstrated the anticonvulsant effects of the aqueous leave extract of Leucas martinicensis in both electrically and chemically induced seizures in rats. The extract exhibited dosedependent protection in the MES and STR tests. Further, like diazepam, the extract provided 100\% protection at 200 and $400 \mathrm{mg} / \mathrm{kg}$ in the STR and 400 $\mathrm{mg} / \mathrm{kg}$ in MES models. However, in lower doses than these, the extract failed to protect the animals in the two models. Nevertheless, in unprotected animals, $L$. martinicensis significantly increased seizure latency and reduced duration of seizure compared with the control group in all models at all tested doses.

Electrically induced seizures have proven to be effective againstgeneralized tonic-clonic and partial seizures in humans (Delgado and Remers, 1998). In MES-induced seizure, L. martinicensis not only protected the animals against seizures but also increased the onset and reduced the duration of seizures in the unprotected rats. Protection against HLTE in MES-induced seizures suggests the ability of a substance to prevent the spread of seizure discharge from the epileptic focus in the brain. It also implies the suppression of generalized tonic-clonic and partial seizures (White, 1997; Hosseinzadeh and Parvardeh, 2004). The ability of the extract to inhibit the HLTE in MES induced seizure suggests anticonvulsant activity for the management of generalized tonic-clonic and partial seizures.

Chemicallyinduced seizure was used to further study the anticonvulsant properties of this extract. STR acts as a selective competitive antagonist that blocks the inhibitory effect of glycine at all glycine receptors (Parmar and Shiv, 2006). The inhibition of STRinduced seizures by $L$. martinicensis suggests seizure suppression by acting on glycine inhibitory mechanisms and the involvement of glycine receptors. Thus, the observed protection of diazepam or L. martinicensis in the STR test is presumably mediated through the glycinergic pathway. The extract showed more protection in STR test than in MES this suggests that the extract may contain constituents which not only act through glycinergic pathway but may be able to control generalised tonicclonic and partial seizures.

Benzodiazepines exhibit sedative effects by potentiating GABA-ergic pathways (Rang et al., 1999). L. martinicensis in a dose related manner potentiated the sedative ability of diazepam by decreasing sleep latency and increasing duration of sleep. This suggests that the extract could contain some components that activate the benzodiazepine and/or GABA receptor sites in the $\mathrm{GABA}_{\mathrm{A}}$ receptor complex. Decrease in sleep latency and increase in duration of sleep are also central inhibitory effects through the stimulation of the CNS inhibitory pathways (Akah et al., 2007).

\section{CONCLUSION}

The results obtained in the present study suggest that Leucas martinicensis may possess anticonvulsant and sedative activities and thus partly lend pharmacological credence to the use of the plant extract in traditional medicine in the treatment of epilepsy and convulsions. Further studies are required to isolate and characterise the active compounds in the extract.

\section{REFERENCES}

Abubakar, K., Ugwah-Oguejiofor, C.J., Usman, M.N., Abubakar, S.B. and Abdulkadir, R. (2013). Evaluation of the Anticonvulsant Effect of the Methanol Extract of Evolvulus alsinoides in Mice. Scholars Academic Journal of Pharmacy, 2(6): 436-441.

Agra, M.F., Freitas, P.F. and Barbosa-filho, J.M. (2007). Synopsis of the plants known as medicinal and poisonous in Northeast of Brazil. Brazilian Journal of Pharmacognosy, 17(1): 114-140.

Akah, P.A., Okoli, C.O. and Ndu, O.O. ( 2007). Experimental methods in physiology and pharmacology. ABIC Books and Equip. Ltd (2nd ed.) Enugu, Nigeria, pp. 161-162.

Alexopoulos, A.V. (2013). Pharmacoresistant epilepsy: Definition and explanation. Epileptology, 1: 38-42.

Amabeoku, G.J., Green, I. and Kabatende, J. (2007). Anticonvulsant activity of Cotyledon orbiculata L. (Crassulaceae) leaf extract in mice. Journal of Ethnopharmacology, 112:101-107.

Czuczwar, S.J. and Frey, H.H. (1986). Effect of morphine and morphine-like analgesics on susceptibility to seizures in mice. Neuropharmacology, 25: 465-469.

Delgado, J.N. and Remers, W.A. (1998). Wilson and Gisvold's Textbook of Organic and Medicinal Pharmaceutical Chemistry. Lippincott-Raven, U.S.A.

Ezeh, U.A., Bello, S.O., Etuk, E.U., Ameh, G.I., Ugwah, O.M. and Ugwah-Oguejiofor, C.J. (2013). Phytochemical and preliminary toxicological studies of the aqueous leave extract of Leucas martinicensis in wistar rats. International Journal of Medicinal Plants Research, 2:166-169. 
Hedge, I.C. (1990). Labiatae. In: Flora of Pakistan, Ali, S.I. and Nasir, Y.J. (eds.). Department of Botany, University of Karachi, Karachi, p.192.

Hosseinzadeh, H. and Parvardeh, S. (2004). Anticonvulsant effects of thymoquinone, the major constituent of Nigella sativa seeds in mice. Phytomedicine, 11: 56-64.

Loscher, W. and Schmidt, D. (2002). New horizons in the development of antiepileptic drugs. Epilepsy Research, 50: 3-16.

Minja, M.M.J. (1999). The Maasai Wonder Plants. Tropical Pesticides Research Institute, Arusha, Tanzania, p. 3.

Muhammad, S., Fatima, A and Yahaya, M.M. (2012). The Phytochemical Components of Leucas Martinicensis that Cause Repellence of Adult Mosquito. International Journal of Modern Botany, 2: 1-5.

Ngo Bum, E., Schmutz, M., Meyer, C., et al. (2001). Anticonvulsant properties of the methanolic decoction of Cyperus articulatus (Cyperaceae). Journal of Ethnopharmacology, 76:145-150.

Ngo Bum, E., Taiwe, G.S., Moto, F.C.O., et al. (2009). Anticonvulsant, anxiolytic and sedative properties of the roots of Nauclea latifolia Smith in mice. Epilepsy and Behaviour, 15: 434-440.

Organization for Economic Development (2008). Principles of Good Laboratory Practice. In: hand Book of Good Laboratory Practice (GLP) TDR, PRD/GLP/01.2.

Parmar, N.S. and Shiv, P. (2006). Screening Methods in Pharmacology. Narosa Publishing House, New Delhi.

Patil, M.S., Patil, C.R., Patil, S.W. and Jadhav, R.B. (2011). Anticonvulsant activity of aqueous root extract of Ficus religiosa. Journal of Ethnopharmacology, 133: 92-96.

Rang, H.P., Dale, M.M. and Ritter, J.M. (1999). Pharmacology. Churchill Livingstone, London/New York.

Reddy, M.K., Viswanathan, S., Sambantham, P.T., Ramachandran, S. and Kameswaran, L. (1986).
Effects of Leucas aspera on experimental inflammation and mast cell degranulation. Ancient Science Life, 5:168-171.

Saha, K., Mukherjee, P.K., Das, J., Mandal, S.C., Pal, M. and Saha, B.P. (1998). Hypoglycemic activity of Leucas lavandulaefolia Rees. In streptozotocin-induced diabetic rats. Phytotherapy Research, 11: 463-466.

Sasa, M. (2006). A New Frontier in Epilepsy: Novel Antiepileptogenic Drugs. Journal of Pharmacological Science, 100: 487-494.

Scharfman, H.E. (2007). The Neurobiology of Epilepsy. Current Neurology and Neuroscience Report, 7: 348-354.

Valsaraj, R., Pushpangadan, P., Smitt, U.W., Adsersen, A. and Nyman, U. (1997). Antimicrobial screening of selected medicinal plants from India. Journal of Ethnopharmacology, 58: 75-83.

Wambebe C. (1985). Influence of some agents that affect 5-hydroxy-tryptamine metabolism and receptors on nitrazepam-induced sleep in mice. British Journal of Pharmacology, 84: 185-191.

White, H.S. (1997). Clinical significance of animal models and mechanism of action studies of potential antiepileptic drugs. Epilepsia, 38: S9S17.

World Health Organisation (1996). WHO Guideline for the Assessment of herbal medicines. WHO Expert Committee on specification for pharmaceutical preparation. Technical Report series no. 863 Geneva.

Ya'u, J., Yaro, A.H., Abubakar, M.S., Anuka, J.A. and Hussaini, I.M. (2008). Anticonvulsant activity of Carissa edulis (Vahl) (Apocynaceae) root bark extract. Journal of Ethnopharmacology, 120: 255-258.

Yemitan, O.K. and Adeyemi, O.O. (2005). CNS depressant activity of Lecaniodiscus cupanioides. Fitoterapia, 76: 412-418. 